\title{
Caminhos da liberdade: os significados da educação dos escravizados
}

\author{
Alexandra Lima da Silval (D
}

\section{RESUMO}

O objetivo deste trabalho é discutir os significados da educação de escravizados no século XIX. Muitos estudos no âmbito da historiografia da educação sinalizam para a importância de ações diversas em torno da escolarização de libertos, ingênuos e escravizados. $\mathrm{O}$ trabalho procura mapear a produção acadêmica existente acerca da temática e indicar a existência de muitos caminhos e possibilidades envolvendo esse objeto de investigação. $\mathrm{O}$ presente trabalho analisa fontes variadas, tais como periódicos, escritas autobiográficas, filmes, na busca por uma compreensão dos caminhos construídos pelos sujeitos escravizados. A educação é compreendida como uma brecha para a conquista da mobilidade e ascensão social em tempos de escravidão. A educação foi parte do movimento de resistência dos escravizados e representou para muitos um caminho para a conquista da liberdade.

\section{PALAVRAS-CHAVE}

escravizados; educação; liberdade; história da educação.

'Universidade do Estado do Rio de Janeiro, Rio de Janeiro, RJ, Brasil. 


\title{
PATHWAYS TO FREEDOM: THE MEANING OF TEACHING ENSLAVED PEOPLE
}

\begin{abstract}
The objective of this paper is to discuss the meanings of education for enslaved people in the 19th Century. Many studies in the field of education historiography point to the importance of various actions regarding the schooling of enslaved people and freedmen. This research attempts to map out existent bibliography focusing on this theme and to indicate the existence of many paths and possibilities around this research object. This project analyzes various sources, such as newspapers, autobiographical writings, and movies, in the search for understanding the paths trod by enslaved subjects. Education is understood as an entry way for social mobility and ascension in times of slavery. Education was part of the resistance for enslaved people and, for many of them, it represented a path toward attaining freedom.
\end{abstract}

KEYWORDS

enslaved people; education; freedom; resistance; history of education.

\section{CAMINOS DE LA LIBERTAD: LOS SIGNIFICADOS DE LA EDUCACIÓN DE LOS ESCLAVIZADOS}

\section{RESUMEN}

El objeto de este trabajo es discutir los significados de la educación de los esclavizados en el siglo XIX. Muchos estudios en el ámbito de la historiografía de la educación apuntan hacia la importancia de distintas acciones alrededor de la escolarización de libertos, ingenuos y esclavizados. El trabajo busca rastrear la producción académica existente acerca del tema e indicar la existencia de muchos caminos y posibilidades alrededor de este objeto de investigación. El presente trabajo analiza variadas fuentes, tales como periódicos, escrituras autobiográficas, relatos de viajeros, películas, en la búsqueda por una comprensión de los caminos que los sujetos esclavizados construyeron. Se comprende la educación como una brecha para la conquista de movilidad y ascensión social en tiempos de esclavitud. La educación formó parte del movimiento de resistencia de los esclavizados y para muchos de ellos representó un camino para la conquista de la libertad.

PALABRAS CLAVE

esclavizados; educación; libertad; resistencias; historia de la educación. 


\section{INTRODUÇÃO}

A primeira cena do filme O nascimento de uma nação (The Birth of a Nation, 2016), baseado em fatos reais, traz como foco o menino escravizado Nat Turner (1800-1831) manuseando um livro que possivelmente pertencia ao filho de seu senhor. O jovem cativo, mostrando que era capaz de soletrar palavras, despertou o interesse de sua senhora em alfabetizá-lo, o que ela fez recorrendo a trechos da Bíblia. Nat Turner foi um escravo americano que se tornou letrado e pastor, sendo líder de uma rebelião escrava no Sul dos Estados Unidos, em 1831(Styron, 1985). O medo quanto ao poder da palavra escrita motivou muitas leis proibitivas acerca da educação dos escravizados (Graham, 2011). Todavia, apesar da existência dessas leis não permitindo a educação de escravos, muitos foram os casos daqueles que às margens tiveram acesso ao universo da cultura letrada nos Estados Unidos (Hager, 2013).

"O conhecimento torna um homem incapaz de ser escravo". Eis uma das frases mais emblemáticas de Frederick Douglass (1818-1895), intelectual afro-americano nascido na escravidão nos Estados Unidos e grande defensor da educação como emancipação dos escravizados. Autodidata, o acesso às letras ampliou a revolta de Douglass contra a escravidão. Tornou-se leitor dos discursos dos pensadores Sheridan, Chatam, Pitt e Fox. "Eu os lia, os relia. Ensinaram-me a dar uma linguagem ao meu pensamento. Os direitos do homem, de todo homem, vieram-me das palavras de Sheridan" (Gazeta da Tarde, 29/5/1883, p. 2). Aprender a ler e a escrever foi um ato de resistência para Frederick Douglass, pois tivera de enfrentar o descontentamento do marido de sua senhora, que considerava bastante perigoso para a escravidão a existência de um escravo instruído.

Assim como Nat Turner e Frederick Douglass, muitos foram os escravizados capazes de ler e escrever nos Estados Unidos que tiveram suas trajetórias conhecidas e pesquisadas, entre os quais destaco os escritos, em primeira pessoa, de sujeitos como Booker Washington (1856-1915), Harriet Ann Jacobs (1813-1897), Amanda Smith (1837-1915), e tantos outros que publicaram autobiografias na forma de livro (Blassingame, 1977). Com base nas escritas de si de diferentes personalidades, dos relatos de missionários, entre outras fontes, o livro Self-Taught: African American education in slavery and freedom, de Heather Williams, explora os esforços dos próprios sujeitos, escravizados e libertos, na luta pela educação e ressalta também a importância da atuação de grupos diversos, tais como missionários religiosos, indicando o poder político possibilitado pelo conhecimento da palavra escrita nos Estados Unidos (Williams, 2005). As autobiografias de escravizados também são fontes fundamentais para o livro Word by word. Emancipation and the act of writing, de Christopher Hager, no qual o autor analisa a importância do domínio da palavra escrita para a conquista da emancipação (Hager, 2013). As autobiografias de escravizados são importantes fontes para uma história da educação mais plural também no Brasil (Silva, 2014,2016), pois permitem a compreensão dos diferentes caminhos empreendidos pelos sujeitos no sentido de se educarem, apesar da escravidão.

Trabalhos acadêmicos situados nas áreas de Educação, História e Letras trazem importantes contribuições para o debate acerca da educação da popu- 
lação afrodescendente, nascida livre, escrava ou liberta. Conforme indicado por Barros (2005b), um dos caminhos possíveis para o estudo de tal questão pode ser justamente o uso de fontes de cunho autobiográfico, pois esse tipo textual apresenta elementos para se pensar os distintos processos de escolarização e trazem à tona a presença negra na escola, que nem sempre era vista de forma otimista ou positiva.

Ao examinar o relato autobiográfico de Helena Morley, por exemplo, Surya Aaronovich Pombo de Barros evidencia o olhar receoso e preconceituoso da normalista em ter que lecionar para crianças negras, lamentando: "que será de mim se for obrigada a largar a Escola, estudo, minhas colegas e tudo para ir ensinar a meninos pretos e burros no Rio Grande?” (Barros, 2005b, p. 8). Ou em outro momento, quando trata a respeito da opinião de Helena Morley para indicar a existência de professores negros: "como se pode ser tão bom como o nosso professor Dr. Teodomiro!? Depois meu pai ainda diz que gente escura não presta! Na Escola, pelo menos, os melhores são ele e Seu Artur Queiroga. Os brancos são crus de ruindade" (Barros, 2005b, p. 8).

A preocupação com o problema da educação da população afrodescendente, que não significa necessariamente população escravizada, é crescente na historiografia da educação brasileira. É o que se nota em publicações de artigos, trabalhos em eventos e livros, frutos de pesquisas desenvolvidas em programas de pós-graduação no país. Entre os estudos sobre a temática, selecionei alguns para o debate.

A obra História da educação do negro e outras histórias, organizada por Jeruse Romão (2005), reúne textos de diferentes períodos históricos e regiões do Brasil valendo-se de um conjunto de artigos preocupados com a pauta de uma educação antirracista, seguindo a agenda das ações e projetos envolvendo a lei n. 10.639/2003, que instituiu a obrigatoriedade do ensino de história e cultura africanas e afro-brasileiras (Brasil, 2003). Com base no mapeamento de estudos sobre o negro na história da educação, Surya Aaronovich Pombo de Barros enfatiza a crescente preocupação com o assunto, demonstrando a importância da temática das relações étnico-raciais na área de Educação (Barros, 2015). Pesquisadores do campo da história da educação mobilizam esforços a respeito dessa questão produzindo obras oriundas de pesquisa documental, como $A$ bistória da educação dos negros no Brasil (Barros e Fonseca, 2016), ou artigos na forma de estado da arte (Bastos, 2016).

O problema da escolarização em uma sociedade escravista é explorado por Adriana Silva em análise feita com base na experiência do professor negro Pretextato e na escola exclusiva para negros e pardos na Corte imperial (Silva, 2000). Os conflitos acerca da escolarização nos períodos da abolição e do pós-abolição, no Rio de Janeiro, são as preocupações expostas no artigo "Felismina e Libertina vão à escola: notas sobre a escolarização nas freguesias de Santa Rita e Santana (Rio de Janeiro, 1888-1906)" (Schueler, Rizzini e Marques, 2015). O processo de escolarização de crianças negras em Vassouras, no período de 1871 a 1910, é o foco da tese de Alexandre Ribeiro Neto (2015). A existência de uma escola de música para escravos na Real Fazenda de Santa Cruz, no Rio de Janeiro, está indicada no estudo de Antonio Carlos dos Santos (2009). Para o autor: 
A Real Fazenda de Santa Cruz funcionou como uma instituição formadora e modeladora do indivíduo (escravo negro) procurando "suavizar" as suas maneiras e especializando-o como mão de obra, para suprir as necessidades da própria Fazenda e da aristocracia e comerciantes da cidade do Rio de Janeiro. Essa especialização, datada dos tempos jesuíticos, fez com quem os escravos negros de Santa Cruz fossem requisitados para serviços diversos, inclusive mutheres musicistas eram contratadas. (Santos, 2009, p. 20)

Por sua vez, a dissertação de mestrado de Surya Aaronovich Pombo de Barros, defendida em 2005, explora os caminhos da escolarização da população negra em São Paulo, no período de 1870-1920 (Barros, 2005a), e em sua tese de doutorado a pesquisadora mergulha no universo letrado da população negra na Parahyba do Norte no século XIX, valendo-se da análise de documentos diversos, tais como relatórios, legislação, entre outros (Barros, 2017). Sobre Minas Gerais, Cynthia Greive Veiga indica a forte presença de pobres e negros na escola pública como um advento do governo imperial (Veiga, 2008). A tese de doutorado de Marcus Vinícius Fonseca estuda a presença de pretos, pardos, crioulos e "cabras" nas escolas mineiras do século XIX, utilizando documentação censitária (Fonseca, 2007). Adlene Arantes pesquisa o papel da Colônia Orfanológica Isabel, localizada na província de Pernambuco, na educação de meninos negros, brancos e índios, no período de 1874 a 1889 (Arantes, 2005). Já a dissertação de mestrado de Aldaíres França procura observar os projetos educacionais para trabalhadores negros, livres ou libertos tomando como base a análise da imprensa periódica nas últimas décadas do século XIX (França, 2006). Importante também citar a pesquisa de Graciane Sebrão, que verifica a Escola de Aprendizes de Marinheiros, o Asilo da Santa Casa de Misericórdia, além de escolas noturnas e o Liceu de Artes e Ofícios, instituições que exerceram o papel de escolarizar afrodescendentes, inclusive escravizados, em Santa Catarina (Sebrão, 2015). A tese de Paulo Sérgio Dutra analisa o processo de escolarização da população negra na cidade de Cuiabá. Mato Grosso, no período compreendido entre 1837 e 1890 (Dutra, 2017).

Há também estudos sobre escolas mantidas por associações abolicionistas, voltadas para a educação de escravizados e libertos. A esse respeito, "Escolas de negros", de Monica Luise Santos e Maria das Graças Madeira, é uma importante referência em que as autoras analisam a fundação da Escola Central, criada na cidade de Maceió, Alagoas, pelos abolicionistas filiados à Libertadora Alagoana, em 1887. As autoras pontuam que a escola tinha por finalidade "abrigar crianças negras do sexo masculino beneficiadas pela Lei do Ventre Livre” (Santos e Madeira, 2006, p. 50).

O colégio teve vida efêmera, sendo extinto aos seis anos de existência. Conforme as autoras,

no ano de 1888, a Escola Central apresentava 81 alunos no ensino primário, 22 no ensino de música e $44 \mathrm{em}$ desenho aplicado às artes. Nas oficinas, havia 28 alunos em marcenaria, alfaiataria e sapataria, ambas com 26; tornearia e tipografia, ambas com sete alunos; e nos ofícios de bauleiro, três; e para tamanqueiro, dois aprendizes. (Santos e Madeira, 2006, p. 57) 
A abertura de escolas noturnas para libertos e escravos foi uma das ações de clubes abolicionistas situados na cidade do Rio de Janeiro e adjacências. A luta para a criação de creches para os filhos de escravos e libertos foram ações empreendidas, por exemplo, pelo Clube dos Libertos de Niterói (Villela, 2013). Na cidade do Rio de Janeiro, Roseane Torres e Flávia Souza estudam projetos de grupos abolicionistas envolvendo a educação popular nesse município (Torres e Souza, 2013). $\mathrm{Na}$ Corte imperial, as escolas abolicionistas coexistiram com outras escolas do gênero, existentes em outras cidades e mesmo em províncias do Império. Por meio da análise de periódicos como a Gazeta da Tarde, é possível vislumbrar a existência de projetos voltados para a educação de libertos e escravos, sobretudo no período entre as décadas de 1870 e 1880 (Silva e Mignot, 2017). Já em Pernambuco, em 1874, missionários capuchinos fundaram a Colônia Orfanológica Isabel, cuja finalidade era abrigar crianças órfãs e "ingênuas", meninos negros, brancos e índios (Arantes, 2005). O problema da educação dos "ingênuos", a partir da Lei do Ventre Livre de 1871, é estudado por diferentes pesquisadores (Barros, 2013; Martinez e Pessanha, 2012; Ribeiro Neto, 2017).

Os estudos no âmbito da cultura letrada também procuram problematizar a aquisição e os usos da escrita por escravos e libertos. Tais investigações indicam a importância de documentos, como cartas e autobiografias, para a compreensão dos caminhos construídos pelos sujeitos em busca da liberdade. Todavia, quem escreve os textos dos escravos? Foram eles próprios que redigiram? Onde essas pessoas aprenderam a escrever?

No artigo Writing from the margins: Brazilian slaves and written culture, Sandra Graham apresenta como uma das fontes de estudo a carta da liberta Florença da Silva para sua filha (escrava de nome Balbina), a fim de problematizar os usos e a inserção de escravos e libertos no universo da cultura escrita (Graham, 2007). Por seu turno, Marialva Barbosa (2009) indica as diferentes formas de relação possíveis entre os escravos e a imprensa, incluindo aí aqueles escravizados que circulavam pelas ruas vendendo jornais aos escravos leitores de tais periódicos. A autora segue o rastro dos periódicos e dos anúncios para problematizar as representações produzidas sobre o cativo (Barbosa, 2009, p. 80).

Os múltiplos significados da escrita entre escravos e forros constituem o foco de Maria Cristina Wissenbach, que analisa cartas e procurações formuladas por escravos em São Paulo na segunda metade do século XIX (Wissenbach, 2002). A problematização referente ao processo de aquisição da leitura e da escrita, além da apropriação de textos por escravos e libertos, também é objeto de investigação em outros estudos (Morais, 2007; Moysés, 1994, 1992).

Por meio de cartas, mapas de escolas, legislação e relatórios, Vicente Moreira da Silva examina a presença de escravos e criados nas escolas noturnas de primeiras letras na província do Paraná, no período de 1872 a 1888. Para o autor, "a frequência dos escravos nas escolas noturnas do Paraná durante o século XIX ocorreu sob a forma de negociações" (Silva, 2013, p. 138).

A educação é entendida como um modo de resistência nas averiguações de Perses Maria Cunha, considerando ações da Irmandade de Nossa Senhora do Rosário e São Benedito dos Homens Pretos do Rio de Janeiro, na direção de 
possibilitar o acesso da população afrodescendente à escolarização no século XIX. A autora defende que a irmandade "apresenta a proposta de criar escolas desde o século XIX, estabelecendo assim seu propósito não só de escolarizar os irmãos, dando a eles subsídios para ler, escrever e contar, mas também de educá-los para o exercício da cidadania" (Cunha, 2004, p. 16). Ainda a respeito do papel das irmandades na educação da população afrodescendente, a tese de doutorado de Itacir Marques da Luz adentra as práticas de associativismo como instância educativa importante na província de Pernambuco, na primeira metade do século XIX (Luz, 2014).

Outros estudos avançam para diferentes períodos históricos. Nos idos do século XVIII, com base em observação de testamentos e inventários, Eduardo Paiva indica a existência de escravos que frequentavam escolas, aprendendo a ler e a escrever nesses espaços (Paiva, 2006). Por meio das análises de testamentos e inventários post mortem, foi possível compreender como tais escravos aprendiam.

Já o estudo de Fabio Eduardo Cressoni explora os sermões de Padre Antonio Vieira direcionados aos escravizados africanos no século XVII, compreendidos como ação pedagógica no intuito de promover uma educação dos cativos (Cressoni, 2008).

Feito o balanço do número crescente de estudos, cada vez mais consistentes e relevantes, a respeito da educação da população afrodescendente em âmbito geral, convém interrogar a especificidade do ser escravo, instruído e educado. Por meio do mapeamento dos estudos já produzidos sobre a temática, é possível também traçar um caminho no intuito de pensar como o cruzamento de fontes e perguntas a elas feitas podem ampliar o horizonte de possibilidades a respeito do educar-se na escravidão. Por sua vez, estudos no âmbito da historiografia da educação têm se debruçado sobre a distinção entre instruir e educar, na passagem do século XIX para o século XX, que se manifestava, sobretudo, nas ações voltadas às classes pobres, nas quais as instituições de ensino não deveriam apenas instruir, mas principalmente educar, "incutindo normas de comportamento, hábitos e determinados valores culturais, em detrimento da cultura e dos valores das próprias camadas populares". Desse modo, conforme contribuição de Alessandra Schueler (1999, p. 62):

educar, no sentido de difundir valores morais e comportamentos, instruindo por meio da alfabetização e do ensino de ofícios artesanais ou agrícolas, seriam ações fundamentais para um Estado que necessitava manter hierarquias e distinções sociais em uma sociedade que implodia, tanto do ponto de vista de sua base - fim da escravidão — quanto em relação à grande complexidade social.

Quais os significados de educação dos escravizados? Como e onde tais sujeitos se educavam e se instruíam? Metodologicamente, neste trabalho busco o cruzamento entre empiria e teoria, fundamentando os indícios obtidos nas fontes com as contribuições teóricas da história social, no intuito de não homogeneizar as experiências, pois:

homens e mulheres também retornam como sujeitos [...] não como sujeitos autônomos, "indivíduos livres", mas como pessoas que experimentam suas situações e relações produtivas determinadas como necessidades e interesses e 
como antagonismos, e em seguida "tratam" essa experiência em sua consciência e sua cultura [...]. (Thompson, 1981, p. 50)

A escolha das fontes no presente trabalho foi feita no intuito de pensar a relação estabelecida com o presente, a fim de modificá-lo, na perspectiva de que a maneira como "enxergamos" o passado é mutável, pois "é o presente que questiona e faz as intimações” (Chesneaux, 1976, p. 24).

Do ponto de vista teórico, a educação como resistência e caminho para a emancipação ancora-se na história social naquilo que diz respeito a pensar o fazer-se dos sujeitos, partindo das margens, sendo a educação compreendida como ferramenta de luta dos sujeitos escravizados, uma vez que não se deve ignorar a dimensão relacional das construções sociais, porque que "a história das pessoas comuns - mesmo quando estão envolvidos aspectos explicitamente políticos de sua experiência passada — não pode ser dissociada das considerações mais amplas da estrutura social", no que auxilia a se pensar concepções mais amplas da história, e não uma escrita fragmentada (Sharpe, 1992, p. 54).

Logo, todas as pessoas - homens e mulheres, ricos, negros, indígenas, brancos, governantes e governados, patrões, empregados, escravizados - são sujeitos da história. Os usos das perspectivas teóricas da história social, por exemplo, podem ser indicados como componentes que explicam a multiplicidade de sujeitos no fazer história da educação, em um compromisso de dar visibilidade a outros sujeitos de "fora" dos grandes temas consagrados pela historiografia; em uma preocupação com a compreensão dos nexos e das relações sociais existentes na atividade humana.

\section{CARTOGRAFANDO CAMINHOS E POSSIBILIDADES EM TORNO DA EDUCAÇÃO DE ESCRAVIZADOS}

Do filme Quanto vale ou épor quilo?, dirigido por Ségio Bianchi, baseado em documentação do Tribunal da Relação do Rio de Janeiro/Arquivo Nacional, em finais do século XVIII, destaco a história de Adão, escravo alugado para trabalhar na contabilidade de uma fábrica de erva-mate. Adão sabia escrever e contar muito bem, o que traria muito lucro para seu senhor. Provavelmente a instrução de Adão era considerada um investimento para o seu dono. Como e onde Adão aprendera a escrever e a contar? Adão também sabia ler?

Especificamente sobre a educação de escravizados, ainda há muito o que se interrogar e investigar, com o objetivo de se dar visibilidade às experiências diversas. A atual Escola Municipal Luiz Delfino, localizada no bairro da Gávea, na cidade do Rio de Janeiro, é exemplo de instituição centenária que carrega a memória de ter sido "uma escola para escravos" no século XIX, conforme noticiado pelo Correio da Manhã:

Escola fundada por escravo faz 100 anos

Fundada pelo escravo Zózimo, mais conhecido por Zé Índio, a Escola 8-2-VI Luiz Delfino, que funciona na Rua Marques de São Vicente, 230, completou 
ontem, 100 anos de funcionamento [...]. A Escola Luiz Delfino nasceu do ideal de um escravo que, por esforço próprio, conseguiu transmitir seus conhecimentos. Queria elevar o padrão de vida do povo. Escravo Zózimo morava num casebre construído no terreno da atual Pontifícia Universidade Católica (PUC). Era apadrinhado da tradicional família de Pedro Pereira da Silva. Pedro Pereira da Silva gostava de Zé Índio. E resolveu levá-lo a Europa para fazer companhia a seus filhos. A alfabetização de Zé Índio foi rápida. Conheceu as letras, observou à cultura e ao trabalho. De volta ao Brasil decidiu que iria ensinar, dar um pouco do que havia recebido. A Escola Luiz Delfino nasceu do ideal de um escravo, que, por esforço próprio, conseguiu transmitir seus conhecimentos. Queria elevar o padrão de vida do povo. (Correio da Manhã, 26/8/1971, p. 4)

A escola foi criada em 1871 e os primeiros alunos eram filhos de escravos libertados "mediante pagamento de meia pataca". Com o falecimento de Zé Índio, foi fundada a Escola da Cartilha de Matemática para o Liberto, "que em 1885 foi entregue à Irmandade de Nossa Senhora da Conceição da Gávea, só para meninos" (Correio da Manhã ,26/8/1971, p. 4). Ainda no século XIX, a escola foi apadrinhada por D. Pedro II, recebendo o título de Escola do Imperador (Rio de Janeiro, 2005, p. 45).

Apesar de inúmeros casos que evidenciam a existência de escravizados educados e instruídos, há quem defenda que em virtude das leis proibitivas e da falta de interesse senhorial os escravos não recebiam instrução no Brasil. Para Sandra Graham, a experiência brasileira foi muito diferente da dos Estados Unidos, país em que os protestantes do Sul, no período colonial, educavam os escravizados para a leitura da Bíblia. No Brasil, os católicos "não achavam que fosse seu dever ensinar os cativos a ler a Bíblia" (Graham, 2011). A autora ainda acrescenta:

De qualquer maneira, o acesso às escolas públicas lhes foi restringido. Uma reforma da educação pública, feita em 1854 na capital imperial, juntou no mesmo balaio as crianças com doenças contagiosas, aquelas que não tinham sido vacinadas e os filhos de escravos, e decretou que ninguém que pertencesse a esses grupos poderia frequentar a escola primária. A Bahia seguiu o exemplo do Rio de Janeiro com uma regulamentação provincial, em 1862 - repetida em 1873 - , que proibia os escravos de estudar nas escolas públicas. Em 1881, autoridades baianas exigiram dos alunos matriculados que confirmassem ter entre cinco e 15 anos, que não tinham doenças contagiosas e que não eram escravos. As autoridades achavam que educar os cativos era desnecessário. (Graham, 2011, p. 2)

Há muito que se questionar na perspectiva defendida por Graham. Apenas católicos estiveram presentes no Brasil? E a presença dos viajantes e missionários protestantes, por exemplo? (Reily, 1993). Tomando como base leis e regulamentos da instrução primária e secundária de nove províncias, Barros (2016) analisa as interdições e permissões sobre a presença negra na escola, entre 1835 (ano das primeiras menções à proibição de matrícula a não livres) e 1887 (última proibição à matrícula de escravos). Para a autora: 
Ao contrário de algumas interpretações ainda vigentes na historiografia, não é possível afirmar que negros eram proibidos nas escolas do século XIX. Mesmo a interdição a escravos, presente em grande parte das leis e regulamentos sobre a instrução, deve ser historicizada. Da primeira lei de Minas Gerais (1835) à de São Paulo (1887), é possível verificar uma multiplicidade de textos, tipos de proibições, ausências, e também permissões ao longo do período no que se refere às diversas possibilidades de ser negro no Império brasileiro. (Barros, 2016, p. 603)

Desse modo, apesar da existência de leis proibitivas, é preciso considerar as ações dos diferentes sujeitos e dos próprios escravizados no intuito de promover a educação e a inserção no universo da palavra escrita e do mundo da leitura. Fontes diversas dão conta de pensar as resistências dos sujeitos escravizados na luta por educação. Para além da legislação, fontes como documentação judiciária, periódicos, manuscritos, relatos de viajantes, entre outros, ajudam a pensar as possibilidades envolvendo a educação e a instrução de sujeitos escravizados. Debruçando-se sobre a documentação judicial, por exemplo, o historiador Sidney Chalhoub localizou a ordem de investigação de "um preto que reside na Rua do Valongo, próximo ao teatro e ao qual muitos outros rendem o maior respeito, e que ali vão iniciar-se em princípios religiosos". Suspeitava-se que a casa situada na Rua Larga de São Joaquim funcionasse como escola, "na qual há reuniões de pretos minas a título de escola de ensinar a ler e escrever" (Chalhoub, 1990, p. 187).

Mapeando anúncios de jornais, pode-se identificar que, nos períodos em que havia leis que proibiam o acesso do escravo à escola, muitos deles sabiam ler, escrever, contar, falar francês, tocar instrumentos musicais etc. Ora, a escola não era o único espaço educativo no século XIX. Muitas outras formas e meios coexistiam no período.

Recorrendo a anúncios dos periódicos da época, localizei pistas sobre como poderia ocorrer a instrução dos escravos. Foram analisados anúncios dos jornais em circulação na Corte imperial e adjacências, conforme Quadro 1.

A análise dos periódicos, o cruzamento com outras fontes e com a produção acadêmica a respeito da temática permite que sejam vislumbradas algumas possibilidades que explicam a existência de escravizados instruídos. A educação doméstica aparece como uma das possibilidades de instrução dos escravos no século XIX, uma vez que era prática bastante difundida no período, conforme pesquisas de Vasconcelos (2005). Seguindo essa possibilidade, localizei anúncios de pessoas se oferecendo para trabalhar nas fazendas, o que incluía a instrução de meninos.

Se algum Sr. fazendeiro precisar, para administrar alguma fazenda, de um homem que sabe ler, escrever e contar, e poderá ensinar a alguns meninos da mesma fazenda as primeiras letras, o qual é casado, porém, sem filhos e dá fiador a sua conduta, procure na rua do Rosário, n. 25. (Jornal do Commercio, 4/7/1837, p. 4)

Além da existência de professores nas fazendas, havia também as "preceptoras" estrangeiras (Vasconcelos, 2005) e, conforme sinalizado por Cunha, uma vez que "no interior das grandes fazendas onde as preceptoras ensinavam aos filhos dos fazendeiros a ler e a escrever, as crianças escravas iam travando contato com as 
primeiras letras"(Cunha, 2004, p. 30). Tal possibilidade se torna mais consistente a partir do diálogo com autores como Luiz Carlos Villalta, que se calça nos estudos de Gilberto Freyre para pensar a educação doméstica nos engenhos.

Segundo Gilberto Freyre, os filhos dos senhores de engenhos nordestinos, até meados do século XIX, costumavam fazer seus estudos na casa-grande, onde quase sempre havia uma sala de aula, com capelães ou mestres particulares. Aos sinhozinhos, em alguns casos, juntavam-se os filhos de escravos e outros moleques, todos aprendendo juntos a ler, a escrever, a contar e a rezar. Nas Minas Gerais, no século XVIII, foram inúmeras as pessoas que galgaram níveis superiores de instrução após aprenderem as primeiras letras nas "escolas familiares". (Villalta, 1997, p. 356)

O relato de viajantes é outra fonte que oferece pistas sobre a postura dos senhores com os escravizados no âmbito da casa e os cuidados no que diz respeito à educação desses sujeitos. O reverendo inglês Richard Boys, em observações tecidas acerca de visita ao Rio de Janeiro, escreveu uma carta na qual apresenta indícios sobre a importância de se educar os escravizados.

Aqui temos residindo um embaixador inglês, o sr. Thornton, e aproximadamente 1.500 negociantes ingleses mais os franceses, muitos dos quais sei que favorecem uma sociedade bíblica auxiliar. A maioria deles possui escravos, os

Quadro 1 - Periódicos em circulação no Rio de Janeiro.

\begin{tabular}{|l|c|c|c|c|}
\hline Título & $\begin{array}{c}\text { Ano de } \\
\text { fundação }\end{array}$ & Proprietário & Cidade & Preço \\
\hline $\begin{array}{l}\text { Diário do } \\
\text { Rio de Janeiro }\end{array}$ & 1821 & $\begin{array}{c}\text { Zeferino Vito } \\
\text { de Meirelles }\end{array}$ & Rio de Janeiro & Avulso: 40 réis \\
\hline $\begin{array}{l}\text { Jornal do } \\
\text { Commercio }\end{array}$ & 1827 & Pierre Plancher & Rio de Janeiro & $\begin{array}{c}\text { Assinatura quatro } \\
\text { meses: } 4 \text { mil réis }\end{array}$ \\
\hline $\begin{array}{l}\text { Correio Mercantil, } \\
\text { e Instructivo, } \\
\text { Politico, Universal }\end{array}$ & 1848 & $\begin{array}{c}\text { Francisco José dos } \\
\text { Santos Rodrigues }\end{array}$ & Rio de Janeiro & $\begin{array}{c}\text { Assinatura três } \\
\text { meses: } 4 \text { mil réis }\end{array}$ \\
\hline $\begin{array}{l}\text { Gazeta de Notícias } \\
\text { O Fluminense }\end{array}$ & 1875 & $\begin{array}{c}\text { José Ferreira de } \\
\text { Sousa Araújo }\end{array}$ & Rio de Janeiro & $\begin{array}{c}\text { Assinatura um mês: } \\
1 \text { mil réis }\end{array}$ \\
\hline Gazeta da Tarde & 1880 & $\begin{array}{c}\text { Francisco Rodrigues } \\
\text { de Miranda }\end{array}$ & Niterói & $\begin{array}{c}\text { Assinatura seis } \\
\text { meses: } 5 \text { mil réis }\end{array}$ \\
\hline O Paiz & 1884 & $\begin{array}{c}\text { João José dos } \\
\text { Reis Júnior }\end{array}$ & Rio de Janeiro & Avulso: 40 réis \\
\hline Cidade do Rio & 1887 & José do Patrocínio & Rio de Janeiro & Avulso $40:$ réis \\
\hline
\end{tabular}

Fonte: Banco de dados da pesquisa.

Elaboração da autora. 
quais, naturalmente, eles têm a obrigação de instruir, e não poderiam ser incomodados [por cumprirem essa obrigação]. Daí haver bastante oportunidade para o estabelecimento de uma escola para adultos em casa para o benefício deles próprios. E quanta utilidade isso teria aqui! Pois não devem existir menos de 2 mil escravos, propriedade de negociantes ingleses (eu os estimaria em 3 mil ou 4 mil), inteiramente às ordens de nossos compatriotas. (Boys, 1819 in Reily, 1993, p. 49 apud Silva, 2010)

A presença dos missionários religiosos também não deve ser ignorada como um caminho para a educação dos escravizados. Além das ações da Igreja católica, a presença da Bíblia no império brasileiro deu-se de diferentes maneiras. Uma delas foi por intermédio das ações dos missionários protestantes. Por meio das cartas do pastor metodista Justin Spaulding (1836) é possível saber da presença de classes para "pretos": "temos duas classes de pretos, uma fala inglês, a outra português. Atualmente, parecem muito interessados e ansiosos por aprender [...]" (Reily, 1993, p. 92 apud Silva, 2010, p. 48).

Em Diário de uma viagem ao Brasil, a inglesa Maria Grahan (1785-1842) menciona a atenção dispensada à educação das escravas domésticas, que, "pela maior parte, nasceram na fazenda e foram educadas na casa da senhora" (Graham, 1959, p. 315). A viajante também sugere certa reprovação da convivência "promíscua" entre senhores e escravizados no interior das casas das fazendas.

Vi crianças de todas as idades e cores, correndo de um lado para outro, que pareciam ser tão carinhosamente tratadas como se fossem da família. A escravidão, nestas condições, é muito aliviada e se aproxima antes da dos tempos patriarcais, quando a criada comprada se tornava, para todos os fins, uma pessoa da família. O grande mal está nisto: ainda que os senhores não tratem mal seus escravos, têm o poder de fazê-lo e o escravo está sujeito ao pior dos males contingentes, isto é, o capricho dos semieducados, ou de um senhor mal-educado. Fossem todos os escravos bem tratados como os escravos domésticos dos Afonsos, onde a família reside constantemente e nada confia a estranhos, e a situação dessas pessoas poderia ser comparada, com vantagem, à dos criados livres. Mas o melhor é impossível, e o pior mais que provável, desde que um poder incontrolável de um ser falível pode se exercer sem censura sobre seus escravos. (Graham, 1959, p. 315)

A educação musical das escravizadas é outro aspecto relatado pela viajante inglesa, com destaque para o fato de as escravizadas terem conhecimento de canto trazido do continente africano e da aprendizagem dos cânticos católicos nos engenhos.

Dona Mariana conduziu-nos ao engenho, onde nos deram bancos colocados perto da máquina de espremer, que são movidos por um motor a vapor, da força de oito cavalos, uma das primeiras, senão exatamente a primeira instalada no Brasil. Há aqui 200 escravos, e outros tantos bois, em pleno emprego. A máquina a vapor, além dos rolos compressores no engenho, 
move diversas serras, de modo que ela tem a vantagem de ter a sua madeira aparelhada quase sem despesa. Enquanto estávamos sentados junto à máquina, Dona Mariana quis que as mulheres que estavam fornecendo as canas, cantassem, e elas começaram primeiro com algumas de suas selvagens canções africanas, com palavras adotadas no momento, adequadas à ocasião. Ela lhes disse então que cantassem os hinos à Virgem. Cantaram, então, com tom e ritmo regular com algumas vozes doces, a saudação angélica e outras canções. (Graham, 1959, p. 318)

Para muitas senhoras e senhores, promover a educação dos escravizados relacionava-se a princípios religiosos, mas também aos interesses em obter benefícios diversos com a posse de um escravo instruído. Mas não apenas no ambiente doméstico os escravizados poderiam ser educados e instruídos.

Os colégios também foram lugares possíveis para a educação de escravizadas, e anúncios de venda de homens e mulheres cativos ajudam a conferir tal possibilidade.

Mucama prendada. Vende-se uma perfeitíssima mucama muito prendada, sabendo cortar e fazer camisas de homem e vestidos de senhora, por qualquer figurino que se lhe apresente, perita engomadeira, borda e marca muito bem, cozinheira de forno, fogão e massas, faz doces de todas as qualidades, penteia e prega uma sephora com toda a perfeição, é a mais prendada que tem aparecido, de bonita figura, moça e bem feita, e também sabe ler e escrever porque andou no colégio, está própria para um fazendeiro que tenha família por ela fazer as vezes de uma boa modista francesa, na rua da Conceição, n. 32. (Jornal do Commercio, $1 / 3 / 1853$, p. 3 , grifos meus)

Entre as muitas qualificações destacadas pelo vendedor ressalta-se o fato de a "mucama prendada" ser perita em muitas coisas, além de saber costurar, ser boa cozinheira e também "saber ler e escrever porque andou no colégio". Uma vez que a escrava estava à venda, é possível aferir que fosse por um valor alto no mercado, em virtude do investimento em sua instrução e do diferencial no mercado.

Outro anúncio de venda de mucama, datado de 1856, diz: "vende-se uma mucama muito prendada [...] sabe ler e escrever, falar francês e tocar piano, por ter sido educada em um colégio, cozinha de forno e fogão, faz doces de todas as qualidades, e é de muito boa conduta" (Jornal do Commercio, 28/11/1856, p. 3). O motivo da venda da prendada mucama seria "por causa da retirada de seu senhor para fora, afiança-se de todas as estas prendas e dá-se a contento para casa de família" (Jornal do Commercio, 28/11/1856, p. 3). Interessante observar que a instrução recebida pela escrava do anúncio se assemelha à instrução de muitas meninas de famílias abastadas no período (Vasconcelos, 2005). Pelo relato de mulheres como Ina Von Binzer, que, além de ter sido preceptora de crianças ricas, também atuou como professora em um colégio para moças, é possível saber um pouco mais sobre o que se ensinava nos colégios para moças no século XIX: 
Rio, 12 fevereiro de 1882

Queridíssima Grete!

Já estou precisando escrever novamente, pois imagine só: desde anteontem estou contratada para um colégio daqui. Um colégio é um liceu para moças, com pensionato; tenho que lecionar quatro classes, iniciando as filhas deste país nos segredos das línguas alemães e inglesa. Além disso, darei inúmeras aulas de piano. (Binzer, 1980, p. 65)

Se, por um lado, os anúncios dão visibilidade às ações de senhores e senhoras no intuito de instruir e educar as escravizadas e os escravizados, estudos como os de Cunha (2004) evidenciam a importância das escolas das irmandades religiosas, como a Irmandade de Nossa Senhora do Rosário e São Benedito dos Homens Pretos, que, em 1859, mantinha um curso de alfabetização para escravizados. Conforme sinalizado por Cunha (2004), entre os compromissos da Irmandade de Nossa Senhora do Rosário e São Benedito dos Homens Pretos, inicialmente datados de 1831, figuram:

$\S^{\circ}$ - Cuidar da educação dos filhos legítimos dos irmãos que morrerem em indigência, contanto que estes tenham pelo menos um ano de recebidos na irmandade, promovendo a entrada daqueles nas escolas de ler escrever e contar, ministrando os socorros para isso necessários, à proporção das rendas da mesma irmandade. $\S 4^{\circ}$ - Libertar da escravidão os irmãos cativos. (Cunha, 2004, p. 40)

A escola foi aberta um pouco depois do regulamento da Instrução Pública Primária e Secundária da Corte, em 1854, o qual proibia o acesso dos escravos à escola.

Art. 69. Não serão admitidos á matricula, nem poderão frequentar as escolas:

$\S 1^{\circ}$ Os meninos que padecerem moléstias contagiosas.

$\S 2^{\circ}$ Os que não tiverem sido vacinados.

$\S 3^{\circ}$ Os escravos. (Cunha, 2004, p. 46)

Na perspectiva de Cunha, foi exatamente a proibição de acesso dos escravos às escolas que levou a irmandade a criar uma instituição específica para essa população, impedida de frequentar escolas públicas (Cunha, 2004, p. 46). Essa seria uma escola diferente, não voltada para uma formação meramente para o trabalho.

Idealizada pelos negros e para os negros, ela valoriza somente o domínio da leitura e escrita, nos moldes das escolas elementares. Nela não se faz presente a preocupação em profissionalizar, preparar mão de obra, mas busca dar a essas crianças o domínio daquilo que em vários momentos foi negado aos escravos: o acesso à escola e à condição de quem não apenas sabe ler e escrever, mas exerce práticas sociais. (Cunha, 2004, p. 47) 
Da década de 1870 em diante, a educação dos "ingênuos" foi pauta constante em debates acirrados de políticos e intelectuais. Do ponto de vista da lei, "o menor" passaria a ser responsabilidade do senhor ou do Estado.

Os ditos filhos menores ficarão em poder o sob a autoridade dos senhores de suas mães, os quais terão obrigação de criá-los e tratá-los até a idade de oito anos completos. Chegando o filho da escrava a esta idade, o senhor da mãe terá opção, ou de receber do Estado a indenização de $600 \$ 000$, ou de utilizar-se dos serviços do menor até a idade de 21 anos completos. No primeiro caso, o Governo receberá o menor, e lhe dará destino, em conformidade da presente lei (Lei n. 2.040, de 28 de Setembro de 1871). (Cunha, 2004, p. 46)

"Caridade e benevolência" passam a ser alegações de muitos senhores para justificar a oferta de trabalho em troca de roupa, educação e comida. Não há, nesse tipo de relação, o reconhecimento da igualdade ou da remuneração pelo trabalho prestado pelo dito "menor de cor":

$\mathrm{Na}$ fazenda do Centro, S. Ex. inaugurou uma escola noturna de ingênuos com 50 alunos, dando o abastado proprietário dessa fazenda o nome de S. Ex. à escola. Ainda mais, por intervenção de S. Ex. vai estabelecer uma linha telefônica entre as vilas do Itapemerim e do Cachoeiro. (O Paiz, 30/5/1885, p. 2)

Ou ainda:

O português José Oliveira Muniz, abastado fazendeiro na Freguesia do Bom Jesus de Itabapoana, município de Campos, está dando aos vizinhos um exemplo, digno de imitação e aplausos. Dispensou os ingênuos, filhos de suas escravas dos anos de serviço a que estavam obrigados, dividiu entre eles as ações que possuía de diversas companhias e admitiu em sua fazenda um professor de instrução primária para os ensinar a ler e escrever. Se todos o imitassem, outra seria a sorte dos ingênuos tão descurada até hoje. (Gazeta da Tarde, 11/2/1881, p. 3)

O debate sobre a educação dos ingênuos também esteve presente em diversos jornais, entre os quais destaco o artigo "A educação dos ingênuos", na Gazeta Nacional, em 5 de junho de 1887. A Gazeta de Notícias também divulga o debate acerca da educação dos ingênuos, conforme análise de Pessoa (2016). Ainda quanto à lei de 1871, alguns estudos ajudam a pensar as ações imperiais no sentido de "educar os ingênuos". Katia Geni Cordeiro Lopes (2012) examina a Escola da Imperial Quinta da Boa Vista como um dos espaços de instrução elementar com a presença de negros, "criada e mantida pelo Imperador D. Pedro II, designada, inicialmente, para atender aos filhos dos empregados da Casa Imperial e dos moradores da Imperial Quinta" (Lopes, 2012, p. 25). Outra iniciativa do governo imperial é estudada por Adriana Valentim Beaklini e revela a presença de escravizados na Escola Mixta da Fazenda Imperial de Santa Cruz (Beaklini, 2013). Por seu turno, o trabalho de Maria Zelia Maia de Souza ressalta a presença de ingênuos no Asilo de Meninos Desvalidos, 
"instituição asilar que fez parte do vasto conjunto heterogêneo de experiências a que a população de ingênuos, órfãos, pobres e/ou abandonados” (Souza, 2008, p. 20).

Conforme noticiado na Gazeta da Tarde, uma solução para o problema dos ditos filhos das escravas seria a educação para o trabalho, evitando assim a mendicância e a criminalidade.

Aprendizes de marinheiros

O presidente do Rio de Janeiro acaba de expedir a seguinte circular aos juízes de órfãos dos diferentes termos daquela província:

"Declaro a Vmcê, para seu conhecimento e fins convenientes, que em aviso circular de 27 do mês findo, comunicou o ministro da agricultura ter resolvido enviar os filhos de mulher escrava, entregues ao Estado, em virtude da opção de que trata o art. 1 da lei n. 2040 de 28 de setembro de 1871, para as companhias de aprendizes, que se acham desfalcadas e onde aqueles menores podem receber educação conveniente." Antes assim que serem consumidos pela polícia. (Gazeta da Tarde, 5/10/1882, p. 1)

As páginas dos jornais também estampam anúncios referentes à loteria para angariar fundo em favor da educação dos ingênuos. Conforme contribuições de Alessandra Schueler, desde meados do século XIX verifica-se acentuada preocupação com a educação de crianças, jovens e adultos das camadas populares livres e libertos por meio de projetos de escolarização, seguindo, nesse sentido, os projetos de saneamento e urbanização das cidades (Schueler, 1999, p. 61).

Acompanhando o movimento de abertura de escolas “para o povo," o boletim da revista $A$ Escola traz o seguinte informe:

Escola do Povo de Itapetininga. Os Srs. Pedro Augusto de Azevedo Marques, José Antonio Pereira Mestre, José Manoel de Almeida, Alfredo Augusto da Silveira e Daniel José de Mattos fundaram em Itapetininga um estabelecimento de instrução com o título Escola do Povo, a qual conta 150 alunos, menores e adultos, livres e escravos. Nossos cumprimentos aos fundadores da Escola do Povo. (A Escola, 1877, p. 29)

Nas palavras do informe, a Escola do Povo contava com número elevado de alunos, sendo permitida até mesmo a entrada de escravizados. Nas adjacências da Corte, mais precisamente na cidade de Niterói, é possível verificar a efervescência quanto à educação de libertos e escravos por meio das ações do Club dos Libertos contra a escravidão e da Confederação de Letras e Artes:

Escola para meninos descalços

Escola gratuita para descalças e calçados, quer adultos, quer menores. Ensina-se português, francês e aritmética. Das 7 às 9 horas da noite, na rua de S. Leopoldo, n. 15. (O Fluminense, $1 / 5 / 1887$, p. 4) 
Ainda em Niterói, na seção Echos da Semana, a Revista Illustrada noticia:

o Club dos Libertos, de Niterói, que tão apreciáveis resultados têm apresentado, ora libertando escravos, ora dando-lhes educação, fez um apelo ao público fluminense, pedindo donativos pecuniários para a criação de oficinas, onde serão recebidos os ingênuos. (Revista Illustrada, 1882, n. 310)

Seguindo indícios dos periódicos, é possível localizar a existência de escolas fundadas por clubes abolicionistas voltadas para libertos e escravos na Corte, entre as quais chamo atenção para a Escola Gratuita Noturna do Club Abolicionista do Riachuelo: "O Club Abolicionista do Riachuelo fundou uma escola gratuita noturna que deverá ser inaugurada a 3 do próximo mês" (Gazeta de Notícias, 14/1/1881, p. 1). Além da existência da escola, havia também uma biblioteca mantida pelo Club Abolicionista do Riachuelo.

O Sr. Dr. Aarão Leão de Carvalho Reis, diretor da repartição telegráfica da estrada de ferro D. Pedro II, remeteu ontem ao Sr. M. E. Campos Porto, 25 exemplares da importante obra de Condorcet, $A$ escravidão dos negros, traduzida por S. S, a fim de serem entregues à biblioteca do Club Abolicionista do Riachuelo. (Gazeta de Notícias, 3/7/1881, p. 1)

A prática de doação para a manutenção das escolas abolicionistas é também possível de ser verificada em outros anúncios:

Os Srs. Elesbão \& Figueiredo, estabelecidos com loja de papel, oferecem à escola noturna gratuita do club abolicionista Gutenberg, estabelecida a rua das Flores, n. 97, os seguintes objetos: 2 livros impressos e riscados, 1 livro menor, para assinarem os visitantes, 6 potes de tinta, 4 resmas de papel, 100 taboadas, 18 duzias de canetas, 19 lousas, 6 duzias de lápis de pedra, 50 folhas de mata-borrão, 50 brochuras, 25 tinteiros, 100 cartas do A, B, C, e 3 caixas de giz. (Gazeta de Notícias, 10/2/1883, p. 2)

Outra associação que também dispunha de uma escola era o Club Abolicionista Guttemberg, que "inaugura, no dia 1 de janeiro próximo, às 6 horas da tarde, na Rua das Flores, n. 97, na Corte, uma Escola Gratuita para instrução de menores e adultos livres, libertos e escravos, sem distinção de cor, nacionalidade ou religião" ( $O$ Fluminense, 29/12/1882, p. 2). Além da manutenção da escola gratuita, o Club Abolicionista Guttemberg promovia atividades culturais diversas para angariar fundos, contando com a presença de homens de letras, artistas, operários e representantes da imprensa, de corporações tipográficas e associações literárias etc. (Silva e Mignot, 2017, p. 245).

No que tange às escolas abolicionistas, destaco a Escola Noturna Gratuita da Cancella, que não contava com subvenção pública para manter-se, sobrevivendo basicamente de doações (Silva e Mignot, 2017). Mantida pela Caixa Libertadora José do Patrocínio, que por sua vez era presidida por Israel Soares, liberto que no aniversário de três anos da Escola da Cancella proferiu discurso registrado nas páginas da Gazeta da Tarde. 
Anteontem solenizou a sociedade, nos salões da Escola Noturna e Gratuita da Cancella a sua sessão solene comemorativa do seu terceiro ano e em honra ao moço escritor à sombra de cujo nome se foi abrigar. Às 8 horas da noite, depois de incorporados terem ido os sócios a casa de José do Patrocínio buscá-lo, reunidos grande número de convidados, um liberto, Israel Soares, declarou aberta a sessão. O discurso pronunciado pelo ex-escravizado foi sublime e eloqüente, enorme pelo entusiasmo que provocou. (Gazeta da Tarde, 20/6/1884, p. 2)

Quem era o ex-escravizado que proferiu o discurso? Com base no relato autobiográfico de Israel Soares, publicado no livro Rascunhos e perfis, de Ernesto Sena (1983), é possível saber que, ainda na condição de escravizado, Israel Soares, um autodidata, criou um curso noturno na casa de quitanda da falecida mãe: "e o pouco que eu sabia distribuí com aqueles que nada sabiam” (Sena, 1983, p. 143). A escola era frequentada por libertos e escravizados.

Entre os meus alunos, posso citar alguns: Abel da Trindade, Pedro Gomes, Marcolino Lima, Justino Barbosa, Joaquim Vicente, Venâncio Rosa, Estanislau, Fausto Dias, Vitor de Souza, Tomé Pedro de Souza, Martinha Benedita, Antônia, Eugênia, Rosa, Vitória e Joana, escravos e ex-escravos. (Sena, 1983, p. 143)

Israel Soares também fundou uma sociedade de dança intitulada Bela Amante, nos idos da década de 1870. Assim como a escola noturna, a sociedade de dança também era composta de escravizados, em sua totalidade. Outra iniciativa de Israel Soares, ainda na condição de cativo, foi a fundação da Caixa Libertadora José do Patrocínio, em junho de 1880 . Na opinião do próprio Israel: “De todos os pequenos trabalhos, foi este o de que mais orgulho tenho na minha vida, pois foi nesta ocasião que pude aproximar-me deste grande vulto que se chama José do Patrocínio"(Sena, 1983, p. 144).

Israel Soares integrava a rede de sociabilidade do jornalista e escritor José do Patrocínio. Esse último também atuou como professor de primeiras letras na Escola da Cancella, "na paciência religiosa de um doutrinador" (Cidade do Rio, 21/9/1896, p. 1).

Além das associações e clubes abolicionistas, os professores também se engajavam na luta pelo fim do trabalho escravo. Esse é o caso do Grêmio de Professores contra a Escravidão, fundado em 1884:

Grêmio de Professores Contra a Escravidão

"Os professores abaixo assinados reunidos em um dos salões do Externato Hewitt resolveram fundar uma associação abolicionista; e passam a tratar do assunto $[\ldots]$

A classe dos professores pode prestar relevantes serviços a causa da liberdade. Contamos com eles. E bem merecerão da pátria. (Gazeta da Tarde, 10/4/1884, p. 2) 
Na década de 1880, uma publicação na Gazeta de Notícias denuncia determinado professor por apresentar comportamento e conduta condenáveis para os padrões da época.

Instrução Pública

A S. Ex. O Sr. Ministro do Império,

Pedimos para dirigir sua atenção sobre o modo por que um certo professor público cumpre o regimento interno e o horário da respectiva escola. Começa por ter suprimido os cânticos religiosos que deve iniciar e terminar os trabalhos; além disto, não leciona desenho linear, música, ginástica, aparentando apenas um ensino de ocasião, quando é visitado pelo delegado; [...] O professor em questão (que bem pode ser Santo) retira-se frequentemente da escola para tratar de liberdade de escravos [...], alardeando que nada teme, porque traz fechados na mão o secretario e o delegado efetivo por meio de presentes que lhes dá. Não fornece a escola o material indispensável como sejam: penas, papel, tinta, lápis, giz, réguas, etc., tendo, no entanto, para isso uma consignação que absorve, chegando por sórdida ganância a empregar um aluno matriculado no serviço de varreduras, compras, etc. (Gazeta de Notícias, 2/6/1887, p. 2)

Destaco nesse documento, entre outros aspectos muito interessantes, o fato de o professor em questão ("que bem pode ser Santo") apoiar a escola liberdade de escravo. Qual seria a cor do professor Santo? Tal possibilidade não é infundada, conforme indicam diversos estudos sobre o protagonismo de professores negros na Corte imperial (Ferreira, 2013; Schueler, 2016; Silva, 2000).

Mas não somente professores lutaram contra a escravidão. Há mais exemplos de escravizados que se tornaram professores, conforme evidenciado pela Gazeta da Tarde em 1880:

Aqui mesmo, no Brasil, há exemplos de escravos servindo de mestres, e até de pais a seus senhores. Lembramo-nos, neste momento, de um caso célebre na província da Bahia, de um escravo que aprendeu a ler, escrever e contar e língua francesa; que serviu de pai e tutor de filhinho órfão de seu senhor, e que, a força de sacrifício e evangélica devoção, conseguiu formá-lo doutor em Medicina.

Este sublime herói da tão caluniada raça africada, chamava-se Thomaz, exatamente como o protagonista do imortal romance da divina norte-americana Harriett Breecher Stowe. (Gazeta da Tarde, 29/10/1880, p. 3)

Comparado ao pai Tomás do romance $A$ cabana do pai Tomás, de Harriet Beecher Stowe, datado de 1852, Thomaz não pode ser considerado exceção, pois houve outros escravizados que se tornaram mestres e educadores. Preto Cosme, nascido escravo no Maranhão, em 1830, era alfabetizado. Conquistou a alforria, abriu uma escola de primeiras letras e liderou a Revolta da Balaiada (Engel, 2002, 
p. 590-591). Há também estudos sobre pessoas nascidas na escravidão que se tornaram mestres. Esse foi o caso de Antonio, nascido escravo em 1847 na província de Pernambuco. "Alforriado, o ex-escravo Antonio escolheu o sobrenome Benvenuto Cellini. Nada mais conveniente, pois esse havia sido um importante escultor, ourives e escritor renascentista" (Mac Cord,2014, p.7). Migrante, no ano de 1890 compunha o corpo docente do Instituto Profissional no Rio de Janeiro (Mac Cord, 2014, p. 15).

Nos derradeiros anos da escravidão, os jornais também noticiavam as iniciativas individuais de alguns senhores de escravos, quando estes concediam alforria e promoviam a educação de seus cativos.

O Sr. Carlos José Ribeiro e sua senhora, residentes em Juiz de Fora, concederam carta de liberdade a sua escravizada Raymunda, parda, de 18 anos de idade, e para seu beneficio a colocaram no asilo de órfãos em Barbacena, a cuja irmã diretora entregaram sua carta de liberdade para ser-lhe entregue quando tiver recebido educação conveniente. O Sr. Carlos Ribeiro é nosso correligionário. Apresentamos-lhes as nossas saudações. (Cidade do Rio, 12/11/1887, p. 2)

Além da educação doméstica, dos professores particulares, dos colégios, das escolas e cursos noturnos diversos, outra possibilidade de acesso à instrução foi o autodidatismo, conforme percebido pela trajetória de sujeitos como Luiz Gama. Vendido ilegalmente como escravo pelo pai, conquistou a alforria e tornou-se importante jornalista e rábula no império (Azevedo, 1999; Souza, 2001). Sem dúvida, para as primeiras letras, contou com a ajuda de um amigo:

Em 1847, contava eu 17 anos, quando para a casa do Sr. Cardoso, veio morar, como hóspede, para estudar humanidades, tendo deixado a cidade de Campinas, onde morava, o menino Antônio Rodrigues do Prado Júnior, hoje doutor em direito, ex-magistrado de elevados méritos, e residente em Mogi-Guassu, onde é fazendeiro. Fizemos amizade íntima, de irmãos diletos, e ele começou a ensinar-me as primeiras letras. (Gama, 1882 apud Schwarz, 1989, p. 140)

Depois da conquista das primeiras letras, seguiu estudando de forma autodidata, escrevendo, lendo e, conforme escreveu em sua carta autobiográfica: "fiz versos; escrevi para muitos jornais; colaborei em outros literários e políticos, e redigi alguns" (Gama, 1882 apud Schwarz, 1989, p. 140). Saber ler, escrever e contar possibilitou a Luiz Gama a conquista de direitos para si e para outros sujeitos escravizados, os quais, como advogado, ajudou a libertar. $\mathrm{O}$ autodidatismo esteve presente na experiência de muitos escravizados e libertos e foi altamente difundida no Brasil do século XIX, uma vez que "somos um país de autodidatas que se esforçaram por formar a própria escola" (Alves, 1936, p. 15). O esforço do próprio sujeito no intuito de educar-se não deve ser menosprezado nas análises, pois

o autodidata tinha, muitas vezes, um entendimento desigual e difícil, mas era seu. Como tinha sido obrigado a encontrar seu próprio caminho intelectual, pouco tomou de empréstimo: sua mente não se movia dentro da rotina estabelecida de uma educação formal. (Thompson, 1988, p. 48) 
Com base em anúncios de periódicos da época, é possível conectar sujeitos localizados em diferentes posições sociais, como o caso de Januário e Julieta. Ele, "preto", possivelmente escravo do Major Pires Ferreira. Ela, nascida livre, filha de oficial de exército:

Januário e Julieta

O major Pires Ferreira, distinto oficial do exército, tem uma interessante filhinha chamada Julieta, e na hora de apresentar-lhe a sociedade, no dia de seu batizado, a 15 do corrente, Fê-la acompanhar de seu dedicado amigo, o preto Januário, de 29 anos, excelente oficial de carpinteiro, a quem mandara ensinar a ler e a escrever. Foram dois batismos, Julieta recebia na pia um nome encantador e Januário, o direito de cidadão. (Gazeta da Tarde, 21/11/1883)

A intenção do pequeno anúncio era dar visibilidade ao batizado da dupla. Porém, interessa aqui, em especial, a menção ao fato de que Januário fora enviado para receber instrução, além de ter o ofício de carpinteiro. O batismo, a profissão e a instrução seriam formas de inserção de Januário nos direitos de cidadania. O debate acerca do exercício pleno da cidadania passava pela alfabetização, pois, a partir da reforma eleitoral de 1881, fora estabelecida a exigência de saber ler e escrever para votar.

Todavia, o impedimento de participação nas eleições no país não reprimiu o processo de luta desses sujeitos na obtenção de direitos, nem os inibiu de se envolverem na vida política em busca de uma cidadania plena. Muito pelo contrário, só fez crescer o número de iniciativas de instrução popular, bem como o aumento das pressões desses sujeitos. O surgimento de clubes e associações — instituições para pobres, libertos e escravizados, entre outras - era parte do movimento de muitos sujeitos que almejavam conquistar direitos em tempos de escravidão.

\section{CONSIDERAÇÕES FINAIS}

Ao término deste artigo, defendo que os significados da educação dos escravizados eram distintos para sujeitos e instituições. Dessa maneira, a iniciativa dos senhores em promover a instrução de seus escravos era diferente das iniciativas do próprio escravizado, que poderia pagar para instruir-se com um professor particular, ou ainda estudar por conta própria, por meio do autodidatismo. As intenções da Igreja (católica e protestante) e do Estado também não foram as mesmas dos centros abolicionistas e das associações e irmandades de homens pretos, por exemplo.

Pelas evidências apresentadas, é possível afirmar que tanto as escolas como os muitos periódicos e livros didáticos em circulação nas últimas décadas do século XIX tinham a missão de educar os diferentes sujeitos. Além disso, práticas educativas diversas coexistiam - com destaque para as escolas dos centros abolicionistas e das irmandades - e eram amplamente divulgadas pela imprensa periódica. A liberdade se construía efetivamente com a emancipação plena dos sujeitos, o que incluía projetos de educação, em sentido amplo. A inserção do escravizado no universo da cultura 
letrada e da educação representou a possibilidade de "fazer comunicável sua memória e experiência” (Martin-Barbero, 2001, p. 179). Dar visibilidade ao processo de luta dos escravizados em busca de educação é também parte da perspectiva que concebe o escravizado como pessoa humana, e não como mercadoria, coisa, ou apenas força física para a execução de trabalho braçal no "eito". Os escravizados não eram tábula rasa: eram seres humanos complexos, dotados de experiências, culturas, memórias, saberes. Dotados de inteligência e capacidade intelectual, aprendiam, continuamente e de diferentes maneiras, nas brechas, nas margens, nas frestas. Para sobreviver, para resistir.

Educar-se foi uma forma de luta e de seguir em frente em uma sociedade que perseguia, estigmatizava e procurava demarcar - no corpo, no gesto e na fala - o lugar do escravizado. A educação foi uma abertura para a mobilidade e ascensão social de muitos, em uma economia escravista fortemente hierarquizada. Foi marca de distinção para inserção no mundo dos libertos e livres. A instrução, o aprendizado da leitura, da escrita e de tantos outros saberes e habilidades, poderiam permitir melhorias nas condições de vida e de trabalho dos escravizados, possibilitando dignidade e negociação pela ampliação de direitos de cidadania. Educar-se e instruir-se em tempos de escravidão poderia ser um atalho na longa jornada pela conquista da liberdade.

\section{REFERÊNCIAS}

A Escola. Revista Brasileira de Educação e Ensino. Rio de Janeiro, 1877-1878.

Alves, I. Vida e obra do Barão de Macabubas. Rio de Janeiro: Ed. Infância e Juventude, 1936. Arantes, A. O papel da Colônia Orfanológica Isabel na educação e na definição dos destinos de meninos negros, brancos e indios na provincia de Pernambuco (1874-1889). 2005. Dissertação (Mestrado em Educação) - Universidade Federal de Pernambuco, Recife, 2005.

Azevedo, E. Orfeu de Carapinha: a trajetória de Luiz Gama na imperial cidade de São Paulo. Campinas: Editora da UNICAMP, 1999.

Barbosa, M. Escravos letrados: uma página (quase) esquecida. E-Compós, Brasília, DF: Associação Nacional dos Programas de Pós-Graduação em Comunicação, v. 12, n. 1, p. 1-19, jan./abr. 2009.

Barros, S.P. Negrinhos que por ahi andão: escolarização da população negra em São Paulo (1870-1920). 2005. Dissertação (Mestrado) — Faculdade de Educação, Universidade de São Paulo, São Paulo, 2005a.

. Fontes para a história da educação da população negra em São Paulo. In: Reunião Anual da Anped, 28., 2005, Caxambu. Anais... Caxambu: ANPEd, 2005b. v. 1. p. $1-16$.

. O estado da arte da pesquisa em história da educaşão da populaşão negra no Brasil. 1. ed. Vitória: SBHE; Virtual Livros, 2015.

.Escravos, libertos, filhos de africanos livres, não livres, pretos, ingênuos: negros nas legislações educacionais do XIX. Educação e Pesquisa, São Paulo: Universidade de São Paulo, v. 42, n. 3, p. 591-605, 2016. http://dx.doi.org/10.1590/S15179702201609141039 
. Universo letrado, educação e população negra na Parabyba do Norte (século XIX). São Paulo: USP, 2017.

Barros, K. Educação e “ingênuos” em Goiás: 1871-1888. 2013. Dissertação (Mestrado em Educação) — Universidade Federal de Goiás, Departamento de Educação, Goiânia, 2013. Barros, S.; Fonseca, M. V. A história da educação dos negros no Brasil. Niterói: EdUFF, 2016. Bastos, M. H. A educação dos escravos e libertos no Brasil: vestígios esparsos do domínio do ler, escrever e contar (séculos XVI a XIX). Cadernos de História da Educação, Uberlândia: UFU, v. 15, n. 2, p. 743-768, 2016. http://dx.doi.org/10.14393/chev15n2-2016-15

Beaklini, A. Escola Mixta da Imperial Fazenda de Santa Cruz: uma proposta de educação pelo trabalho do imperador D. Pedro II (1885-1889). 2013. Dissertação (Mestrado em Educação) - Universidade Federal do Estado do Rio de Janeiro, Rio de Janeiro, 2013. Binzer, A. Os meus romanos - alegrias e tristezas de uma educadora alemã. 2. ed. Rio de Janeiro: Paz e Terra, 1980.

Blassingame, J. W. Slave testimony: two centuries of letters, speeches, interviews and autobiographies. Baton Rouge: Louisiana State University Press, 1977.

Brasil. Lei n. 10.639, de 9 de janeiro de 2003. Altera a lei n. 9.394, de 20 de dezembro de 1996, que estabelece as Diretrizes e Bases da Educação Nacional, para incluir no currículo oficial da Rede de Ensino a obrigatoriedade da temática "História e Cultura AfroBrasileira", e dá outras providências. Diário Oficial da União, Brasília, DF, 10 jan. 2003.

Chalmoub, S. Visões da liberdade: uma história das últimas décadas da escravidão na Corte. São Paulo: Companhia das Letras, 1990.

Chesneaux, J. Devemos fazer tábula rasa do passado? Sobre a história e os historiadores. Rio de Janeiro: Editora Ática, 1976.

Cressoni, F. Educação de escravos africanos: uma leitura de Vieira. 2008. Dissertação (Mestrado em Educação) — Universidade Metodista de Piracicaba, Piracicaba, 2008. Cunha, P. M. Educação como forma de resistência: o caso da Irmandade de Nossa Senhora do Rosário e São Benedito dos Homens Pretos. 2004. Dissertação (Mestrado em Educação) - Universidade Federal Fluminense, Niterói, 2004.

Dutra, P. S. No correr da pena: processos de escolarização da população negra na cidade de Cuiabá (1837-1890). 2017. Tese (Doutorado em Educação) — Universidade Federal Fluminense, Niterói, 2017.

Engel, M. Preto Cosme. In: Vainfas, R. Dicionário do Brasil imperial. Rio de Janeiro: Objetiva, 2002. p. 590-591.

Ferreira, H. O protagonismo social de professores negros da Corte na produção de experiências escolares independentes (Rio de Janeiro, século XIX). In: Simpósio Nacional de História, 27., 2013, Natal. Anais... Natal: ANPUH, 2013.

Fonseca, M. V. Pretos, pardos, crioulos e cabras nas escolas mineiras do século XIX. 2007. Tese (Doutorado em Educação) - Universidade de São Paulo, São Paulo, 2007.

FRAnçA, A. Uma educação imperfeita para uma liberdade imperfeita: escravidão e educação no Espírito Santo (1869-1889). Vitória: Universidade Federal do Espírito Santo, 2006. 
Graham,M.Diário de uma viagem ao Brasil. São Paulo: Companhia Editora Nacional, 1959. Graham, S. Writing from the margins: Brazilian slaves and written culture. Comparative Studies in Society and History, Cambridge, Reino Unido: Cambridge University Press, v. 49, n. 3, 2007, p. 611-36. https://doi.org/10.1017/S0010417507000643

. O poder das letras. Revista de História da Biblioteca Nacional, Rio de Janeiro: Fundação Biblioteca Nacional, Sociedade de Amigos da Biblioteca Nacional Sabin, 2011. Disponível em: <http://www.revistadehistoria.com.br/secao/capa/o-poder-dasletras>. Acesso em: 29 jan. 2017.

Hager, C. Word by word: emancipation and the act of writing. Cambridge, MA: Harvard University Press, 2013.

Lopes, K. G. A presença de negros em espaços de instrução elementar da cidade Corte: o caso da Escola da Imperial Quinta da Boa Vista. 2012. Dissertação (Mestrado em Educação) - Programa de Pós-Graduação em Políticas Públicas e Formação Humana, Universidade do Estado do Rio de Janeiro, Rio de Janeiro, 2012.

Luz, I. Laços da diáspora: associacionismo e educabilidade entre a população negra de Pernambuco na primeira metade do século XIX. 2014. Tese (Doutorado em Educação) - Universidade Federal de Minas Gerais, Belo Horizonte, 2014.

MAc CoRd, M. Antonio Benvenuto Cellini: a trajetória de um escultor da escravidão à liberdade. Recife/Rio de Janeiro, século XIX. Revista do Arquivo Geral da Cidade do Rio de Janeiro, Rio de Janeiro: AGCRJ, n. 8, p. 399-413, 2014.

Martin-Barbero, J. Dos meios às mediações. Rio de Janeiro: Editora da UFRJ, 2001.

Martinez, A.; Pessanha, A. Gazeta Nacional e a educação de ingênuos. Imprensa do Rio de Janeiro, 1888. In: Encontro Regional de História Anpuh-Rio, 15. 2012, São Gonçalo. Anais... Rio de Janeiro: ANPUH-Rio, 2012. p. 1-8.

Morais, C. Ler e escrever: habilidades de escravos e forros? Comarca do Rio das Mortes, Minas Gerais, 1731-1850. Revista Brasileira de Educação, Rio de Janeiro: ANPEd; Campinas: Autores Associados, v. 12, n. 36, 2007, p. 493-504. http://dx.doi. org/10.1590/S1413-24782007000300008

Moysés, S. Entre-tempos: alfabetização e escravidão. 1992. Tese (Livre Docência) Universidade Estadual de Campinas, Campinas, 1992.

. Leitura e apropriação de textos por escravos e libertos no Brasil do século XIX. Educação Ẽ Sociedade, Campinas: CEDES, v. 15, n. 48, p. 200-212, 1994.

Paiva, E. Leituras (im)possíveis: negros e mestiços leitores na América Portuguesa.In: Dutra, E. F; Mollier, J. Y. (Orgs.). Política, nação e edição: o lugar dos impressos na construção da vida política no Brasil, Europa e Américas nos séculos XVIII-XIX. São Paulo: Annablume, 2006. p. 481-493.

PessoA, R. Instrução primária e profissional na Gazeta de Notícias (1875-1888). Dissertação (Mestrado em Educação) — Universidade Federal Fluminense, 2016.

Reily, D. A. História documental do protestantismo no Brasil. São Paulo: ASTE, 1993.

Ribeiro Neto, A. Acalanto: ensinando as primeiras letras aos filhos dos libertos em Vassouras (1871-1910). In: Mac Cord, M.; Araújo, C.; Gomes, F. Rascunhos cativos: educação, escolas e ensino no Brasil escravista. Rio de Janeiro: 7Letras, 2017. 
. Fios do novelo: crianças negras, educação e trabalho em Vassouras, 1871 a 1910. 2015. Tese (Doutorado em Educação) — Programa de Pós-Graduação em Educação, Universidade do Estado do Rio de Janeiro, Rio de Janeiro, 2015.

Rio de Janeiro. Secretaria Municipal de Educação - Semed. Escolas do imperador. Rio de Janeiro: Secretaria Municipal de Educação, 2005.

Romão,J.História da educação do negro e outras histórias. Brasília, DF: SECAD, 2005. Santos, M. L.; Madeira, M. G. L. Escola de negros. In: Cavalcanti, B. C. et al. (Orgs.). Kulé Kulé. Maceió: EDUFAL, 2006. p. 51-61.

. A educação de meninos negros na Escola Central em Maceió (1881-1893). Trabalho de Conclusão de Curso (Curso de Pedagogia) — Universidade Federal de Alagoas,Maceió, 2008. Santos, A. Os músicos negros. Escravos da Real Fazenda Santa Cruz no Rio de Janeiro (1808-1832). São Paulo: Annablume; FAPESP, 2009.

Schueler, A. F.M. Crianças e escolas na passagem do Império para a República. Revista Brasileira de História, São Paulo: ANPUH, v. 19, n. 37, p. 59-84, set. 1999. http:// dx.doi.org/10.1590/S0102-01881999000100004

Schueler, A. F. M.; Rizzini, I.; Marques, J. Felismina e Libertina vão à escola: notas sobre a escolarização nas freguesias de Santa Rita e Santana (Rio de Janeiro, 1888-1906). História da Educaşão, Porto Alegre: FACED/PPGEdu, v. 19, p. 145-165, 2015. https:// doi.org/10.1590/2236-3459/46047

Schueler, A. F. M. Trajetórias cruzadas e ação docente em luta por educação: André Rebouças, José do Patrocínio e Manuel Querino. In: Fonseca, M. V.; Barros, S. A. P. (Orgs.). A bistória da educação dos negros no Brasil. 1. ed. Niterói: EDUFF, 2016. v. 0, p. 191-216.

Sebrão, G. Educação dos negros em Santa Catarina: narrativas, expectativas, experiências (1850-1889). Tese (Doutorado em Educação) — Programa de Pós-Graduação em Educação, Universidade do Estado do Rio de Janeiro, Rio de Janeiro, 2015.

SenA, E. Rascunhos e perfis. Brasília, DF: UnB, 1983.

Sharpe,J. A história vista de baixo. In: Burke, P. A escrita da história: novas perspectivas. São Paulo: UNESP, 1992. p. 39-62.

SiLva, A. M. P. Aprender com perfeição: escolarização e construção da liberdade na Corte na primeira metade do século XIX. Brasília, DF: Plano, 2000.

Silva, A. L. Escritores da liberdade: autobiografias de escravos, memória e história da educação. Educação em Foco, Belo Horizonte: UEMG, ano 19, n. 28, p. 103-132, maio/ago. 2016.

. Narrativas de vida de ex-escravos como fonte/objeto para a história da educação. In: Vasconcelos, M.; Cordeiro, V.; Vicentini, P. (Orgs.). (Auto) biografia, literatura e história. 1. ed. Curitiba: CRV, 2014.v. 1, p. 129-145.

Silva, A. L.; Mignot, A. C. V. Pelos caminhos da liberdade: sujeitos, espaços e práticas educativas (1880-1888). In: VenÂncio, G. M.; Secreto, M. V.; Ribeiro, G. S. Cartografias da cidade (in) visivel. Setores populares, cultura escrita, educação e leitura no Rio de Janeiro. Rio de Janeiro: Mauad X, 2017. 
Silva, H. O. A Igreja presbiteriana do Brasil e a escravidão: breve análise documental. Fides Reformata, São Paulo: Centro Presbiteriano de Pós-Graduação Andrew Jumper, v. 15, n. 2, p. 43-66, 2010.

Silva, V. Escravos e criados nas escolas noturnas de primeiras letras na provincia do Paraná (1872-1888). 2013. Dissertação (Mestrado em Educação) — Universidade Estadual de Maringá, Maringá, 2013.

Souza, M. C. Preto no branco: a trajetória de escritor de Luiz Gama. In: VIDAL, D.; Hilsdorf, M. L. Brasil 500 anos. Tópicos em história da educação. São Paulo: Edusp, 2001.p. 97-115.

Souza, M. Z. Educar, civilizar, trabalhar no Asilo de Meninos Desvalidos (1875-1894): caminhos possíveis. 2008. Dissertação (Mestrado em Educação) — Universidade Federal do Estado do Rio de Janeiro, Rio de Janeiro, 2008.

Schwarz, R. Autobiografia de Luiz Gama. Novos Estudos, São Paulo: CEBRAP, n. 25, 1989, p. 136-141.

Styron, W. As confissões de Nat Turner. Tradução de Vera Neves Pedroso. Rio de Janeiro: Rocco, 1985.

. O termo ausente: experiência. A miséria da teoria ou um planetário de erros. Rio de Janeiro: Zahar, 1981.

. A formação da classe operária inglesa III. A força dos trabalhadores. Rio de Janeiro: Paz e Terra, 1988.

Torres, R.; Souza, F. Liberdade e instrução: projetos e iniciativas abolicionistas para a educação popular (Rio de Janeiro, década de 1880). In: CArula, K.; Engel, M.; CorrêA, M. L. (Orgs.). Os intelectuais e a nação. Educação, saúde e a construção de um Brasil moderno. 1. ed. Rio de Janeiro: Contra Capa, 2013. v. 1, p. 49-84.

Vasconcelos, M. C. A casa e os seus mestres. A educação no Brasil dos Oitocentos. Rio de Janeiro: Gryphus, 2005.

VEIGA, C. G. Escola pública para os negros e os pobres no Brasil: uma invenção imperial. Revista Brasileira de Educação, Rio de Janeiro: ANPEd; Campinas: Autores Associados, v. 13, n. 39, p. 502-516, 2008. http://dx.doi.org/10.1590/S1413-24782008000300007

VILlela, H. O movimento abolicionista niteroiense, o Clube dos Libertos e o projeto de uma creche para filhos de escravos e ex-escravos. In: Congresso Brasileiro de História da Educação, 7., 2013, Cuiabá. Anais... Cuiabá: SBHE, UFMT, 2013.

Villalta, L. C. O que se fala e o que se lê: língua, instrução e leitura. In: Souza, L. M. (Org.). História da vida privada no Brasil: cotidiano e vida privada na América portuguesa. São Paulo: Companhia das Letras, 1997. p. 331-387.

Williams, A. Self-Taught: African American education in slavery and freedom. Chapel Hill: University of North Carolina Press, 2005.

Wissenbach, M. C. Cartas, procurações, escapulários e patuás: os múltiplos significados da escrita entre escravos e forros na sociedade oitocentista. Revista Brasileira de História da Educação, Maringá: Sociedade Brasileira de História da Educação; Campinas: Autores Associados, v. 2, n. 2(4), jul./dez. 2002. 


\section{FILMES}

O NASCIMENTO DE UMA NAÇÃo. Direção e produção Nate Parker. Elenco: Nate Parker, Armie Hammer, Mark Boone Junior e mais. Distribuidor Fox Film do Brasil, 2016. 1 DVD (200 min.)

QUANTO VALE OU É POR QUILO? Direção e produção Sergio Biachi. Roteiro: Sérgio Bianchi, Newton Cannito, Eduardo Benaim. Elenco: Ana Carbatti, Cláudia Mello, Herson Capri, Caco Ciocler, Ana Lúcia Torre, Silvio Guindane, Myrian Pires, Lena Roque, Leona Cavalli. Barueri: Europa filmes, 2005.1 DVD (117 min.)

\section{PERIÓDICOS}

CIDADE DO RIO, Rio de Janeiro, 1886-1887.

CoRREIO DA MANHÄ, Rio de Janeiro, 1971.

Correio Mercantil, e Instructivo, Politico, Universal, Rio de Janeiro, 1848-1868.

DiÁRIO do RIo DE JANEIRo, Rio de Janeiro, 1860-1878.

GAZETA DE NoTÍCLAS, Rio de Janeiro, 1875-1888.

GAZETA DA TARDE, Rio de Janeiro, 1881-1888.

GAZETA NACIONAL, Rio de Janeiro, 1887.

JoRNAL DO COMMERCIO, Rio de Janeiro, 1827-1888.

O FLUMINENSE, Niterói, 1880-1888.

O PAIZ, Rio de Janeiro, 1885.

REVISTA ILLUSTRADA, Niterói, n. 310, 1882, Echos da Semana.

\section{SOBRE A AUTORA}

Alexandra Lima da Silva é doutora em educação pela Universidade do Estado do Rio de Janeiro (UERJ). Professora da mesma instituição. E-mail: alexandralima1075@gmail.com 